Journal of Nepal Geological Society, 2019, vol. 58 (Sp. Issue), pp. 83-88

DOI: https://doi.org/10.3126/jngs.v58i0.24576

\title{
Review on Issues and Aspects of Construction Material Mining in Nepal
}

\author{
Uttam Bol Shrestha \\ Ekjati Engineering Pvt. Ltd. Balkumari-18, Mahalaxmi Municipality, Lalitpur \\ Email:uttambol@yahoo.com
}

\begin{abstract}
For the development of nation, it is utmost important that infrastructures such as roads, highways, bridges, buildings etc. be constructed throughout the country. Infrastructure development is impossible without construction materials such as stone, aggregates and sand. They are the one used in huge amount in construction work. In this context, the cost of construction materials plays vital role in development process. Lower the cost of these materials, the cost of infrastructure development will be lower. Therefore, emphasis should be given to reduce their supply cost. The supply cost primarily depends on production cost. The production cost is dependent on process of getting the mining license at the desired place, scale of the targeted production, mining mechanization, mining processing and transportation cost. For this the mining must be run systematically and compatibly with concerned rules and regulations. In this paper, some of the legal shortcomings in existing rules and regulations concerned with mining the construction material is outlined that needs to be incorporated or corrected.
\end{abstract}

Keywords: Construction materials, Mining, Cost of mining, Legal aspects

Paper Received: 15 Jan 2019

Paper Accepted: 7 May 2019

\section{INTRODUCTION}

For the development of the nation, it is utmost important that infrastructures such as roads, highways, bridges, buildings etc. be constructed throughout the country. No such infrastructure development is possible without basic construction material such as stone, aggregates and sand. They are the one used in huge amount in any construction work. In this context, the cost of these construction materials plays vital role in the development process. Lower the cost of these materials, the cost of infrastructure development will be lower. Therefore, emphasis should be given to reduce their supply cost to the consumers. The supply cost of these materials primarily depends on production cost. Production cost, in fact is dependent on their mining inclusive of processing and transportation cost.

The more these materials are produced near the proposed sites of the infrastructures, their transportation cost will be reduced. Hence, wherever possible allowing mining near big infrastructures is an important aspect of lowering their cost. On the other hand, reducing the mining cost is another aspect for lowering their cost. Mining cost is dependent upon the easy process of getting the mining license at the desired place, the scale of the targeted production, mining mechanization, and facilitation for their processing and mine running costs. The more the mining is systematically run with concerned rules and regulations compatibly, it is more easily achievable. Hence, Strength, Weakness, Opportunity and Threat (SWOT) Analysis for the construction material mining is carried out. Based on the results of the analysis, some of the legal aspects to be improved or changed in the present rules and regulation to strengthen the construction material mining industry is outlined.

\section{LEGAL STATUS FOR MINING INDUSTRIES IN FEDERAL NEPAL}

There is clear division of work obligations, duty and power of the federation, state and local governments about development, protection and environmental friendly and sustainable use of natural resources in the Constitution of Federal Nepal, 2072. Mineral resources are also considered as natural resources. Accordingly, the concurrent powers of the Federation, State, and Local levels are vested in the Mines and minerals, Royalty from natural resources, and made an arrangement to exercise such powers pursuant to the Constitution, the Federal law, the State law, and the law made by the Village Assembly or Municipal Assembly (Constitution 2072, 2015).

In the federal level there is a provision of Formation of National Natural Resources and Fiscal Commission (NNRFC) with its Functions, duties, and powers clearly mentioned. The NNRFC defines about setting bases for the determination of shares of the Government of Nepal, State Government and Local level in investments and returns, in the mobilization of natural resources. It also handles about the study and research work on possible disputes that may arise between the Federation and the States, between States, between a State and a Local level, and between Local levels, and make suggestions to act in a coordinated manner for the prevention of such disputes. Further, NNRFC has the functions, duties and powers and rules to mobilize the natural resources or distribution of revenues. In the state level, the executive power includes Exploration and management of mines whereas, in the Local level they must be vested in Protection of watersheds, wildlife, mines, and minerals and such powers shall be exercised pursuant to this Constitution 
and the law made by the Village Assembly or Municipal Assembly (Constitution 2072, 2015).

On the basis of constitution of the federal Nepal 2072, the local government operation act (LGOA) 2074 was formed (LGOA 2074, 2017). LGOA 2074 (2017) has differentiated the Work obligation, duty and power of the Rural Municipality and Municipality in regards with

\footnotetext{
- Watershed, wild life, protection of Mines and Minerals - Implementation and monitoring of local policy, rules and regulation and standards regarding water shade, wild life and protection of mines and minerals

- Information and data base of Mines and minerals

To support in the protection and promotion of precious metal, stones and minerals

- Registration, license issuing, renewal, khareji and management of stone, aggregates, sand, salt, soil, talc and slate

- Geological map publication

- Collection, coordination and regulation of the service charge and, royalty collection of natural resources

- Mining of minerals and royalty collection

- Policy, rules and regulation standards and monitoring of the royalty to be generated by natural resources

- Royalty collection and distribution generated by natural resources
}

\section{MINISTRY OF FEDERAL AFFAIRS AND GENERAL ADMINISTRATION, NEPAL GOVERNMENT}

Ministry of Federal Affairs and General Administration, Nepal Government on 2074.11.22 has issued a letter stating that until the rules and regulation regarding the construction material mining as dictated by mentioned Local Government Operation Act, 2074 (LGOA 2074, 2017), is formulated, the license for mining the construction material is to be issued by the local government after the approval from Department of Mines and Geology according to the Mines and Mineral Act 2042 (MMA 2042, 1984), and; Mines and Mineral Rules and Regulation, 2056 (MMRR 2056, 1999). Until, the process of issuing license for construction materiel mining is continued accordingly.

\section{STRENGTH WEAKNESS OPPORTUNITY AND THREAT (SWOT) ANALYSIS}

The SWOT analysis for the construction material mining in Nepal in reference to the existing rules and regulations regarding the mineral industries are carried out. The purpose is SWOT analysis is to check whether there is a possibility of running construction material mining in an effective, efficient, and economic and environment friendly situations with the existing rules and regulations. Based on the results of the analysis some of the legal aspects and shortcomings in existing rules and regulations concerned with mining the construction material is outlined. Necessary suggestions are given that need to be incorporated or corrected during the amendments in the rules and regulations regarding mines and minerals development.

\section{Strength of construction material mining industry}

1.Nepal is a developing country where lot of infrastructural development such as roads, railways, dams, buildings etc. are needed that consumes construction material in huge amount. Its demand is widely distributed all around the country. There is a big demand of construction material in nearest and easily accessible neighboring countries such as northern states of India and Bangladesh. Therefore, the big market is a strength of the mining industry.

2.Construction material is abundantly available almost throughout the country. Stones and aggregates could be obtained from the mining of the bed rocks and collection of flood plains and river course. Sand could be mined out from the sand mounds, terraces, flood plains and river course and the weathered rocks masses.

3. Lower construction material costs reduce the infrastructure development costs, it generates revenues and helps the nation to industrializations (MMRR 2056, 1999)

4. The export of the construction material to neighboring countries is the source of income generation to the nation. It helps to generate the employment. It helps in developing the allied industries.

5. Due importance on mineral resources development and empowerment to the state as well as the local level in their role in mineral resources development are given by the Constitution of Federal Nepal (Constitution 2072, 2015).

\section{Weakness of construction material mining industry}

\section{Lack of preference}

- Despite the fact that due importance on mineral resource development and empowerment of the state and local government, no new rules and regulations are yet formulated. In the federal Nepal, there is only one centrally located Department of Mines and Geology. Hence, there is no technological control on several construction materials mining taking over different parts of the country.

- The cost incurred in the consumption of cement and 
the construction material (inclusive of sand and cement) at present is about 60 to $70 \%$ of the cost of cement. The cost of aggregate and sand in Kathmandu is about Rs. 45 to Rs. 50 per cft, and the Nepalese cement cost 600/50 $\mathrm{kg}$ bag. Hence, pricewise the cost of aggregate and sand is as important as that of cement to reduce the infrastructural development cost.

- In any infrastructural development projects, sand and aggregates are one used in huge amount leading to larger scale of mining with better mining technology and management, but that has not been listed in the priority list.

- As per Clause 17, and Anusuchi-9 of the Industrial Enterprises Act, 2016, Mineral Industries, Petroleum and Natural gas and Fuel investigation and production industries fall under the National Privileged industries. These industries enjoy several facilities as per the provision of the act (IEA, 2016). However, Construction material mining does not belong to the privileged industries as the Mines and Mineral Act, 2042, clause 12 , sub-clause 4 is instructed to be managed separately (MMA 2042, 1984).

- Mines and Mineral Rules and Regulation, 2056 rule 36 , Sub-rule 4 directs that mining of construction material in forestland and require prior approval of land to use in mining from the Ministry of Forestry and Soil Conservation before its processing in Department of Mines and Geology (MMRR 2056, 1999). The Ministry of Forestry and Soil Conservation is not in condition to approve forestland for mining until the mining scheme is approved by the Department of Mines and Geology. The mining and forest rules are contradicting in using the forestland for construction material mining. This ends the use of forestland land in the construction material mining. Thus, the construction material mining, despite its importance could not carry out except in private land.

- Despite the fact that construction material has to be used many folds more than its binding material cement, it has to carry out EIA for more than 200 cubic metre/day production whereas the limestone, raw material for cement production needs EIA only after 4800 tons/day, i.e., nearly 1850 cubic metre/day (EPR 20541997 and amendments). Why this discrepancy, (?) the threatening to environment is almost the same scale for both the mining. This has hindered in the large-scale construction material mining and its production despite its possibility of export to India and Bangladesh.

- Separate Licensing for construction material processing: Sand washing is an integral part of mining for upgrading the quality of sand, but this requires additional license to work on. Similarly, crusher to produce aggregates and chips are the integral part of mining, which requires additional license to work on. This has not only lengthened the process but created problems in administrating and monitoring.

\section{Weak Rules and regulation}

- The mining of construction material is necessary wherever some large development projects are in process and the more the distance of such mining, the cost of construction material increases, and consequently the development project cost. The mining of the construction material, in general is the mining of stone and sand without any important minerals in them. Therefore, its mining could be processed without disturbing to other license holder such as the Prospecting or mining and within the protected area for special minerals so that the construction material could be supplied to the needy one in cheaper cost. This will help in development process of the country. However, the present mining laws prohibit such process, as there is no provision of issuing license for construction material within the license issued for other minerals and special mineral area. This also hinders in the income of the local government in the present federal Nepal.

- The construction material could be exported to India and Bangladesh if they could be produced at cheap rate and huge amount. This requires large mines area and the present system of providing only $0.25 \mathrm{sq}$. km lease area (Rule 16, sub-rule 3) hinders in the process. Similarly, for small enterprises getting the cluster of 1 hector private land in the mountains and hills with rocks and sand becomes difficult (Rule 16, sub-rule 4). This is mainly due to the inclusion of forest and public land in between where mining of construction material is not allowed at present (MMRR 2056, 1999). This has breaking effect in emerging the small construction material mining at various parts of the country that ultimately makes high the cost of development.

- Mines and Mineral Regulation, 2056 with amendments (Rule 19, Ga) has prohibited all kinds of mining within 50 meters of nationally important places, ancient statues, crematory, public road, pipe line, fort, temples, streams etc. This provision is applicable to all kinds of mining (MMRR 2056, 1999). Yes, in general mining may produce disturbances and may degrade the environment of these area. But, simply saying 50 meters away is not any scientific and enough. They need to be more scientifically and systematically decided. Some of them could not be managed for mining where as some of them could be managed by safely shifting to safe places such as pipe lines, electric poles and so-on. On the other hand, this has completely prohibited mining in the riverbed and flood plains. Terrace deposits to be mined within the river terraces are completely prohibited. Several times mining of river sediments and flood collected material is very necessary to safe guard the river course and its environment. The excess river coarse sedimentation and uprising of the riverbed bed need to be cleared off so that the river gets its guided course and no fertile land be eroded as in the case of Terai. 
- Whatsoever be the practical situation, the mines and mineral regulation does not say that construction material processing units such as the crusher and washing plants could not be incorporate within the mining project?

- The requirements to fulfill the Initial Environmental Examination as per the cabinet decision (CD 2070, 2013) of 2070.05.17 are very primitive in nature such as:

- Crusher plants should be away by $500 \mathrm{~m}$ from Raj Marg, $500 \mathrm{~m}$ from riverbank, $2 \mathrm{~km}$ from educational, health institutions, $2 \mathrm{~km}$ settlements, and forest and so on.

- It is ridiculous that the lease area should be only rectangular in shape and must be parallel to the North south direction. The mineral resources occurrences may be in any direction.

- These standards are fixed for the betterment of the environmental conditions, but not worthy for the industries and such land is very difficult to find. This is hindering the development of legal crusher industries.

- The Environmental Protection Act (EPA 2053, 1996; Environmental Protection Rules (EPR 2054, 1997) allows Extraction of sand, gravel, and soil at the rate of more than Fifty cubic meters per day from the surface of river and revolute after Environmental Impact assessment but the mines and Mineral Acts and Rules prohibit such mining as no mining could be carried out within 50 meters of the river (MMRR 2056, 1999).

\section{State of Ambiguity}

All the mining works are considered cause of environmental degradation. In fact this is not true. The excavation considered in the host or country rock or insitu rock may be degrading the environmental if not properly environmental preventive and mitigation measures are taken. Nevertheless, excavation made to maintain the river course, removal of flooded load in the big rivers, does not degrade the environment but help in safeguarding the environment and the soil erosion.

However, this needs due study of the geological conditions, load of the river, its carrying capacity, and the terrains around the depositional area.

- For example: The continuous widening of Rivers and fertile land erosion in the Terai as well as toe erosion widening the rivers in the Chure range is a continuous process, accelerated by non-removal of the river load deposited.

\section{Lack of Human Resources}

There is no system of right man at right place in Nepal. Most of the mining works should have been under the supervision of mining engineers with due support of geologist and other engineers of different field. However, unfortunately, there is no study of mining engineering in Nepal and there exist hardly very few mining engineers (not more than 15) inclusive of retired and old citizens. There seems no preference by the government to prepare such human resources.

- The geologists are trying their best but their effort is also in almost vein as the excavator operator and tripper drivers are considered the right persons by the entrepreneurs of construction material enterprises.

\section{Lack of Technology}

Simple breaking by breakers, loading by excavators, and hauling by trippers are commonly used. Crushers of primitive type jaw crusher are in use.

- Lack of experts of the field has caused lagging in use high technology. Drilling and blasting in hard rocks are also not in use. Present technology of mobile crushing, screening and separating that makes even the dust to useful byproduct are not in use.

- Most of the construction material mining are of small scale producing less than $150 \mathrm{~m}^{3}$ per day stone and 200 cubic metre/day sand.

\section{Opportunity of construction material mining industry}

- The vision of Prosperous Nepal and Happy Nepalese (Samriddha Nepal, Sukhi Nepali) could not be fulfilled until the development activities increases. For any kind of development, infrastructural development is the first goal. For infrastructural development of any kind, construction material is one of the most important parameters. Hence, the political vision has created a very big opportunity in the field of construction material mining (Budget Speech 074/075, 2017).

- There is a big demand of construction material in our neighboring countries such as northern states of India and Bangladesh. The right approach to the construction material mining and its production with political dedication can make these countries our consumer of the construction material.

- Proper excavation and mining of the flood plains of the rivers of Terai in the regular basis and with scientific study of the flood plains, load carrying capacity of the rivers etc. not only could produce construction material but also save the erosion of the fertile land of Terai.

\section{Threat of construction material mining industry}

- The biggest threat of any kind of mining is the environmental degradation and impacts if not properly handled and mitigation measures are taken.

- If not properly handled it may be cause for degradation of roads, causes of accidents, causes of landslides, and destruction of agricultural land down depth etc.

- It may be the cause of physical, social and aesthetical environmental impacts near the mining sites. 


\section{OUTCOMES OF THE SWOT ANALYSIS}

- The construction material mining is one of the means to achieve the Prosperous Nepal and Happy Nepalese vision of the Government. The systematic mining with preference from the government could foster the industry and the new power delegation to the local authority concerning the construction material mining monitoring and royalty collection helps to null the illegally running mines.

- It helps in reducing the cost of infrastructure development within the country and the reduced cost of production with political dedication; it could be export to neighboring countries, which helps in generating the foreign currency.

- The fertile land erosion of the Terai, landslides, and toe erosions of the Siwaliks could be reduced my channeling the rivers course and extracting the flood lodes regularly in close supervision of the geoscientists and mining engineers.

The mining industries, not only the construction material mining but also others such as limestone and so-on is in the emerging state and government must give emphasis in generating the concerned human resources such as mining engineers, geoscientists and so-on.

- Mining industries, construction material, as well as other minerals may wear and tear the environment due emphasis must be laid to safeguard the environment.

\section{CONCLUSIONS}

- The construction material mining with their processing produce construction material which if could carry systematically, environmental friendly and abundantly it plays vital role in the development of the nation by reducing the cost of development. It could also be the source of foreign income generation. However, there are many shortcomings, legally, technically as well as in practical implementations. Similarly, political dedication is also equally warranted for its development.

- Some of the shortcomings could be overcome by implementing the suggestions and recommendations given below. Therefore, these suggestions are recommended to encompass while formulating the new Policies, Acts or Rules and regulation where ever applicable in Federal Nepal.

\section{SUGGESTIONS AND RECOMMENDATIONS}

- Formulate the new rules and regulations regarding the construction material mining at earliest possible. Make easy legal requirements that could be fulfilled and avoid illegal mining. Make licensing process easy. Expand the Department of Mines and Geology in all the states at the earliest.

- Give facility to utilize the national as well as public land for construction material mining work. Make simple process to acquire public as well as forest land required for construction material mining. Government must help in the land acquisition process.

- Make one window policy for mining licensing and royalty collection. Processing of construction material must be included within the Mineral Work. Provide the status of National privileged Industry for the Construction material mining and its processing. Increase the range of production for IEE as that for the limestone mining.

- Do not constrain the construction material mining to private land only until it directly affects the mining of other minerals and badly impacts the environment. Allow the mining as per the availability of the resource and safe mining without environmental impacts. Do not restrict the mines lease area to 0.25 square kilometer. Allow the lease area in any definable regular shape that could be referenced with north direction.

- Make free from primitive unscientific clauses of prohibiting the mining within $50 \mathrm{~m}$ of several constraints mentioned in that sub-rule, but make sure that these require safeguarding and mitigating measures. Quantify each affecting factor, such as river suspends in $\mathrm{m} 3 / \mathrm{sec}$, sound in decibels etc. Similar is the case for their processing plants such as crushers and washing plants.

The mining work falls within the spectrum of mining engineers, therefore the government must give preference to develop such human resources like, mining engineers, mining overseers, mining geologists etc.

- Illegal excavation made in several forms such as flattening sloppy lands, developing fishery ponds etc., for excavating construction material rather than the same purpose must be stopped.

- Whatsoever may be the cause of mining, excavation, infrastructure development, it should be given due consideration to the environment and safeguard our mother earth without whose existence we all will be in vain.

\section{REFERENCES}

Budget Speech 2074/2075, 2017, Budget speech of Fiscal Year 2074/2075 delivered to Joint Assembly of Federal Parliament by Honorable Finance Minister Dr. Yuba Raj Khatiwada, Government of Nepal Ministry of Finance 2075, 86p.

CD 2070, 2013, Cabinet decisions, 2070, 47-meeting, Government of Nepal, $4 \mathrm{p}$.

Constitution 2072, 2015, The Constitution of Federal Nepal, 2072 published in Nepal Gazette, Government of Nepal, $252 \mathrm{p}$.

EPA 2053, 1996, Environmental Protection Act, Nepal Gazette, www.lawcommission. Government of Nepal, 2053, 57p.

EPR 2054, 1997, Environmental Protection Regulations with amendments, Nepal Gazette, part 3, section-65, Number28, 2054, 4p. 
IEA, 2016, Industrial Enterprises Act, 2016: “Cause-17 Company Rules, Schedule-9”, published by Nepal Law commission, Government of Nepal, 112p.

LGOA 2074, 2017, Local Government Operation Act, www.lawcommission. Gov.np. Nepal Gazette, 2074, Government of Nepal, 83 p.
MMA 2042, 1984, Mines and Mineral Act, published in Nepal Gazette, 2042, Government of Nepal, 9p.

MMRR 2056, 1999, Mines and Mineral Regulation with Amendments, Nepal Rajpatra, first published 2056, Forth amendments, 2073, Government of Nepal, 60p. 